\title{
Lumen
}

Selected Proceedings from the Canadian Society for Eighteenth-Century Studies

\section{The Performative Birth of the German Nation out of War in German Eighteenth-Century Historiography: Johann Wilhelm von Archenholz' History of the Seven Years' War}

\section{Stephan Jaeger}

Volume 27, 2008

North America at the Crossroads of European Cultures in the Eighteenth Century

L’Amérique du Nord au Carrefour des cultures au XVIII ${ }^{\mathrm{e}}$ siècle

URI : https://id.erudit.org/iderudit/1012052ar

DOI : https://doi.org/10.7202/1012052ar

Aller au sommaire du numéro

Éditeur(s)

Canadian Society for Eighteenth-Century Studies / Société canadienne d'étude du dix-huitième siècle

ISSN

1209-3696 (imprimé)

1927-8284 (numérique)

Découvrir la revue

Citer cet article

Jaeger, S. (2008). The Performative Birth of the German Nation out of War in German Eighteenth-Century Historiography: Johann Wilhelm von Archenholz' History of the Seven Years' War. Lumen, 27, 85-98.

https://doi.org/10.7202/1012052ar

Copyright (C Canadian Society for Eighteenth-Century Studies / Sociéte canadienne d'étude du dix-huitième siècle, 2009
Ce document est protégé par la loi sur le droit d'auteur. L'utilisation des services d'Érudit (y compris la reproduction) est assujettie à sa politique d'utilisation que vous pouvez consulter en ligne.

https://apropos.erudit.org/fr/usagers/politique-dutilisation/ 


\section{The Performative Birth of the German Nation out of War in German Eighteenth-Century Historiography: Johann Wilhelm von Archenholz' History of the Seven Years' War}

German history's lack of a national narrative in the eighteenth-century

In the eighteenth century, German history lacked unifying incidents that could be used to form a national narrative. Whereas, for example, the British developed a new narrative style in historiography ${ }^{1}$ which was based on a mostly omniscient third-person voice from the perspective of zero-focalization (unlocatable, behind the events), ${ }^{2}$ German historiography had not been able to achieve any such narrative unity. German historiography was either focused on a knowledge-based approach in the tradition of historia literaria, an approach which lacked the narrative skills of emplotment necessary to create a coherent meaning in history, or it reflected on the theoretical and methodological aspects of historiography, an approach which enhanced the development of

1 Cf. Laird Okie, Augustan Historical Writing: Histories of England in the English Enlightenment (Lanham: University Press of America, 1991), and Everett Zimmerman, The Boundaries of Fiction: History and the Eighteenth-Century British Novel (Ithaca: Cornell University Press, 1996).

2 For a general summary of the theoretical implications of historiography and perspective, see Philippe Carrard, Poetics of the New History: French Historical Discourse from Braudel to Chartier, Parallax: Re-visions of Culture and Society (Baltimore: Johns Hopkins University Press, 1992). 
a philosophy of history. ${ }^{3}$ Eighteenth-century Germany was split into many small principalities and therefore lacked national stories. Consequently, its historiography became either more purely local on the one hand or philosophical and universal, without referring to specific historical events, on the other.

\section{Johann Wilhelm von Archenholz' History of the Seven Years' War}

Around 1790, the branch of German historiography concerned with historical events and political history finally developed the representational means to create historical unity on a national or on a universal level. This unity was not found in history itself, on the story level, but in the act of historical writing, on the discourse level. The texts of the era achieve this unity by employing a performative and dramatic style that draws the reader into the narrative thrust of historical events and developments.

The staging of the past in historiographical texts gives history meaning, while for example in the more realistic German nineteenth-century historiography, story and discourse are separated from each other. Two seminal performative historiographical texts are Friedrich Schiller's Secession of the United Low-Countries from the Spanish Government (1788) ${ }^{4}$ and Johann Wilhelm von Archenholz' History of the Seven Years' War (1793). ${ }^{5}$ In this article, I will focus on the latter.

3 Cf. Daniel Fulda, Wissenschaft aus Kunst: Die Entstehung der modernen deutschen Geschichtsschreibung 1760-1860, European Cultures: Studies in Literature and the Arts 7 (Berlin: de Gruyter, 1996), 49-263.

4 Cf. Stephan Jaeger, "Die Beredsamkeit des Prinzen von Oranien oder Friedrich Schillers ästhetische Erfindung modernen Geschichtsdenkens," in Ästhetische Erfindung der Moderne? Perspektiven und Modelle 1750-1850, ed. Britta Herrmann and Barbara Thums, Stiftung für Romantikforschung 17 (Würzburg: Königshausen und Neumann, 2003), 95-114, and Johannes Süssmann, Geschichtsschreibung oder Roman? Zur Konstitutionslogik von Geschichtserzählungen zwischen Schiller und Ranke (1780-1824), Frankfurter Historische Abhandlungen 41 (Stuttgart: Steiner, 2000), $75-112$.

5 Johann Wilhelm von Archenholz, Geschichte des Siebenjährigen Krieges in Deutschland von 1756-1763 in Aufklärung und Kriegserfahrung: Klassische Zeitzeugen zum Siebenjährigen Krieg, ed. Johannes Kunisch, Bibliothek der Geschichte und Politik 9 (Frankfurt a.M.: Deutscher Klassiker Verlag, 1996), 9-513. This text is referenced as $G D K$ in the text in all future citations. Unless otherwise noted, all translations from the German are my own. 
Johann Wilhelm von Archenholz was a Prussian commander during the Seven Years' War. He entered the army of the Prussian king and commander-in-chief, Frederick II, in December 1758, at the age of fifteen, and participated in the siege of Dresden and in several other key battles of the war, such as the battles at Liegnitz and Torgau in 1760. In November 1760, he was appointed to the rank of officer. After the war, he resigned his commission, along with his promotion to commander and his nobilitation. ${ }^{6}$ Later on, Archenholz became one of Germany's most important cultural publicists and an advocate of the Enlightenment, publishing the travel book England and Italy in 1785 and founding and editing one of the most renowned and successful historical-political journals of that time, Minerva. ${ }^{7}$ Although he was an eyewitness to many events of the Seven Years' War, Archenholz, for the most part, subordinates this perspective in favour of maintaining an analytical distance with regard to his subject-matter. He does not provide much new historical material, but critically evaluates his sources and maintains the importance of oral history by other eyewitnesses. He finds most of the historical details in the military history of the Seven Years' War by the Prussian colonel G. F. Tempelhof, ${ }^{8}$ an account which is rich in military detail, but very defensive about Prussian strategies and far from the modern historical narrative, which typically creates historical meaning and unity. Herein lies Archenholz' innovation: he uses narrative technique to create meaning in history without disregarding the facts that contradict this meaning.

\section{The Battle of Leuthen}

The most striking example of Archenholz' technique of performative history is his narrative of the Battle of Leuthen, which took place on December 5, 1757. At the outset of the 1757 campaign, the Prussians seemed doomed to lose the war. Frederick II is in the worst imaginable situation: the Prussians seem to have lost Silesia, and the Austrians are

6 Ute Rieger, Johann Wilhelm von Archenholz als "Zeitbürger": eine historisch-analytische Untersuchung zur Aufklärung in Deutschland, Quellen und Forschungen zur brandenburgischen und preußischen Geschichte 4 (Berlin: Duncker und Humblot, 1994), $23 f$.

7 Rieger, Johann Wilhelm von Archenholz, passim.

8 G. F. v. Tempelhof, Geschichte des Siebenjährigen Krieges in Deutschland, Bibliotheca Rerum Militarium 29, 6 vol. (1783-1801; repr. Osnabrück: Biblio Verlag, 1977). 
so superior after their victories at Kollin and Breslau that the end of the war seems imminent, "when - to the amazement of all of Europe - the whole scene changed". ${ }^{9}$ After Archenholz establishes Frederick's hopeless situation and represents the confidence of the Austrians, he turns to Frederick's famous speech in Parchwitz to his generals and higher ranked staff officers. ${ }^{10}$ Other contemporary historiographers - such as Milbiller or Tempelhof - report the result of the speech and summarize all the Prussian qualities which Frederick enumerates to lift the courage and confidence of his commanders and his army. ${ }^{11}$ Archenholz, however, does not report the contents and results of Frederick's speech. He stages its effects. The speech displays a triadic structure of Prussian qualities: courage, desire to serve, and love for the fatherland, which are themselves based on a threefold strength: Prussian ancestors, the army, and the fame of the Prussian name. This triadic structure is exactly reflected in the officers' responses to the speech - enthusiasm, tears, emotion: "By his [Frederick's] solemn speech, he aroused the enthusiasm and spirits of his soldiers; they had tears in their eyes; all were deeply moved". ${ }^{12}$ The paratactic syntax underlines the theatrical structure of the description. The persuasive power of Frederick's speech is enacted for a second time. The reader is not directly listening

9 GDK, 127. Archenholz constantly uses theatrical metaphors and regards history as unfolding events on a stage.

10 For a comparative analysis of the different accounts about this speech, see Dieter Radtke, "Ansprache Friedrich des Großen an seine Generale und Stabsoffiziere vor der Schlacht bei Leuthen: Was hat Friedrich wirklich gesagt?" Zeitschrift für Heereskunde 69,1 (2005): 9-17, and Reinhold Koser, "Vor und nach der Schlacht bei Leuthen: Die Parchwitzer Rede und der Abend im Lissaer Schloß," Forschungen zur brandenburgischen und preußischen Geschichte 1 (1888): 605-18.

11 Tempelhof, Geschichte des siebenjährigen Krieges, vol. 2 [1783], 321-32 - Tempelhof witnessed Frederick's speech (cf. Radtke, "Ansprache Friedrichs," 11); Joseph Milbiller, Geschichte Deutschlands im achtzehnten Jahrhunderte: ein Nachtrag zu Risbek's Geschichte der Deutschen (Zurich: Orell, Gessner, Füßli, 1795), 191-3. In his own historical account of the Seven Years' War, Frederick regards war and history as something that can be planned and executed according to rational calculations. The course of events is usually altered by human mistakes, usually by his officers, not by himself; contingencies do not exist, there is only bad execution. See Die Werke Friedrichs des Großen, ed. Gustav Berthold Volz, transl. Friedrich v. OppelnBronikowski and Thassilo von Scheffer, vol. 3 and 4, Geschichte des Siebenjährigen Krieges 1 and 2 (Berlin: Hobbing, 1913). For the Battle at Leuthen, see vol. 3, 105-9. Originally published in French as L'histoire de la guerre de sept ans, vol. 3 and 4, CEuvres posthumes de Fréderic, roi de Prusse (Berlin: Voss et Decker, 1788). 
to Frederick, but watching both Fredrick and his officers and feeling the powerful effect of the speech in the structure of Archenholz's language, which itself re-invokes the effectiveness of the scene. The speech as subject matter of historical writing overlaps with a style of historiography that creates enthusiasm, and the confluence of style and subject matter establishes the inevitability of the historical turn of events in favor of the Prussians.

Archenholz goes on to emphasize the inferiority of the Prussians in numbers: 33,000 versus 90,000; the disparity in the armies' relative strengths evokes the myth of David against Goliath. The Austrians rely on their size, on their mathematical numbers; the Prussians - after Frederick's speech - on their tactical skills and on their leader. The outcome of the whole battle depends on Archenholz's antithetical representation, which sees the battle as a duel, the momentary shifting back and forth; but in the end, the enthusiasm of the Prussians supersedes the Austrian superiority in numbers. A tactical error by the Austrians shifts the balance of power. According to Archenholz, Frederick's genius and his use of Greek military tactics to make his army appear bigger than it actually is, trigger the error and trap the Austrian army in one place. Unlike his sources, Archenholz does not report the events and results of the battles. Rather, he displays them; he creates a scene in the present. The reader experiences the constant movements back and forth that culminate in the Prussian victory, the improbability of which has been underscored by Archenholz's account of the hopeless situation the Prussians faced at the beginning of the battle. Whereas in the Battle of Kollin, the Austrians won because their "machines," their canons, were set up on inaccessible heights, "at Leuthen, only tactics and bravery determined the victory". ${ }^{13}$

Though Archenholz sticks to the known facts of the battle, his narrative achievement is to stage the Prussian army's characteristic bravery and Frederick's tactical genius. These qualities prevent the Prussians from being defeated by their superior and numerous enemies. Archenholz' historical narrative is modern, since unlike those of his predecessors it maintains a narrative unity. It is guaranteed by the conflict between little Prussia, with only a few Allies, and the European powerhouses, ${ }^{14}$ between the tactical mastery demonstrated by Frederick and the superior numbers of his enemies. However, paradoxically Archen-

14 The Kingdom of Prussia fought with Hanover and some British support against the Austrian and Russian Empires, France, Saxony, etc. 
holz must create a narrative that seems explicitly pre-modern in order to achieve this modern unity. The narrative must be vivid, so that it persuades the reader of the rhetorical necessity of its outcome. Therefore, Archenholz still uses the representational techniques of the old rhetorical, exemplary historiography, but he uses them in a new way, both textually and aesthetically. Frederick's strength is actualized, and the reader believes that history took its necessary course.

\section{Coincidences and Necessities - the Staging of Prussian Values}

A new function of coincidences and necessities became evident in eighteenth-century history as historians stopped employing superior discourses that determined the interpretation of history. Religion alone, for example, could no longer explain historical events and developments. History became an autonomous system or discourse that needed to develop its own laws. As a consequence the primary events in history often appeared to happen without reason. ${ }^{15}$

In the eighteenth-century, the word 'history' ('Geschichte') was used for the first time to describe a single, collective force instead of a compilation of stories ('Geschichten') about the past. The phenomenon that Reinhard Koselleck would call 'Kollektivsingular Geschichte' ('collective singular history') emerged. This new history was characterized by a specific temporal quality: human experiences of time and history became relative issues which depended on the subject's perspective vis à vis the past, the present, and the future. As a result, the exemplary past lost its authority; the past could no longer guarantee the truth, since it depended on the perspective of individual and collective subjects. The idea of the historia magistra vitae was abandoned. ${ }^{16}$

Archenholz is able to accept the incomprehensible aspects of history, since he does not search for definite historical answers in every incident. There are many contingent events: the Prussian king might make mistakes; or a little incident could change the whole trajectory of the

15 For more on this tension between coincidences in history and the idea of a historical continuum in Archenholz' text, see Reinhart Koselleck, "Der Zufall als Motivationsrest in der Geschichtsschreibung," in R. Koselleck, Vergangene Zukunft: Zur Semantik geschichtlicher Zeiten (Frankfurt a.M.: Suhrkamp, 1979), 158-75.

16 Reinhart Koselleck, "Historia Magistra Vitae: Über die Auflösung des Topos im Horizont neuzeitlich bewegter Geschichte," in R. Koselleck, Vergangene Zukunft: Zur Semantik geschichtlicher Zeiten (Frankfurt a.M.: Suhrkamp, 1979), 38-66. 
war. We see Archenholz's modernity in this novel approach. His predecessor Tempelhof is descriptive and very precise in his use of military details; he does not force events into teleological sequences; instead the text moves along in chronological order, but without any narrative unity. ${ }^{17}$ Archenholz adds a narrative component, so that an overall perspective with regard to the war and the course of history becomes possible. For example, the narrative technique used by Archenholz allows one to read Frederick's disastrous defeat at Hochkirch at the end of 1758 as contingent, which explains its lack of historical impact. ${ }^{18}$ Archenholz' narrative is shaped by dramatic turns which are both positive and catastrophic, mostly from the Prussian perspective, and are always dramatized and rhetorically highlighted. These turns become part of an overall narrative structure that points toward the necessary victory and survival of the Prussians. In this way contingent events can be honored in their accidental structure and become part of a necessary and teleological development of history at the same time.

Archenholz uses the constant shifts of fortune in war to highlight the battle between quantitative and qualitative necessities. ${ }^{19}$ For example, in the representation of the Battle at Leuthen, one motif is the improbability of a Prussian survival or victory based on their inferior numbers. Thus, reason suggests that Prussia will fall. This fall might be delayed or accelerated by contingent events, but eventually the fall of Prussia and Frederick II is inevitable. Against this inevitability, Archenholz sets the superior Prussian values and skills: bravery, virtue, tactics, charisma, honor, etc. For example, the Prussians could have won the war as early as 1757, if they had had a few more pontoons to cross the Vltava, and been able to encircle the full Austrian army at Prague. ${ }^{20}$ The narrative constantly moves forward on the basis of the presumption that the war could have ended in favor of either side, though the reality of the Seven Years' War suggests that few of the major battles significantly altered the course of the war.

The teleological element of a Prussian triumph is guaranteed by the constant performance of Prussian values. Archenholz increasingly

17 Tempelhof, Geschichte des siebenjährigen Krieges. The first four volumes of Tempelhof's history had appeared before Archenholz finished his History of the Seven Years' War.

$18 G D K, 184$.

19 For an interpretation of Archenholz' use of the word 'fortune,' see Koselleck, "Der Zufall," 170-5.

20 GDK, 44. 
styles Frederick as the guarantor of victory, ${ }^{21}$ though some of his officers also embody superior qualities. Frederick's General Tauenzien defends Breslau, in another apparently hopeless situation, through his steadfastness and dedication. ${ }^{22}$ If one reads this episode carefully - again, Archenholz sticks to accepted historical facts - one realizes that Tauenzien's successful defense of Breslau can be explained through military reason and logic. In Archenholz' rhetoric, however, Tauenzien defeats the Austrian General Laudon by winning a rhetorical and tactical duel. The two generals negotiate by exchanging letters and Laudon is defeated by Tauenzien's quick-witted and precise replies; the latter's rhetoric becomes increasingly despondent. Again, the narrative argument of Prussia's greatness is proved in the staged performance of history. In another instance, Russians and Austrians have taken Berlin; they are "dreaming" of taking their winter quarters in Brandenburg when Frederick approaches "with the speed of a flood" and his enemies withdraw quickly. ${ }^{23}$ Elsewhere Frederick approaches like the "word of thunder" and the plans of his opponents are frustrated. ${ }^{24}$ In Archenholz's tropes, Frederick becomes a force of nature that supersedes the Austrians' superior numbers.

\section{The Seven Years' War as Historiography's Performative Invention of the German Nation}

At first glance, the triumph of the Prussians, as Archenholz represents it through all the years of the Seven Year's War, and as we have seen it more in detail in the analysis of the Battle at Leuthen, seems to prove mainly the greatness of Frederick and Prussia. A closer look reveals two interrelated subplots that provide a second level of narrative unity. These subplots are the progress of civilization through war and the cul-

21 For an account of Frederick's double function belonging both to the military and to the people, see Jürgen Fohrmann, “Der Ruhm des Königs: Über die Herstellung eines Mythos und seine medialen Bedingungen," (paper presented at the international conference Der Siebenjährige Krieg in den Medien, Halberstadt, Germany, November 27-29, 2003, forthcoming in Der Siebenjährige Krieg in den Medien, ed. Wolfgang Adam and Holger Dainat), manuscript p. 5.

22 GDK, 309-312.

23 GDK, 337f.

24 GDK, 166. 
tural creation of the German nation out of war. The first becomes most clear in Archenholz' résumé at the end of the book:

More than 700,000 warriors had been fighting. And from what peoples! They were not soft Asians who have always covered the field with large armies, so that the Greek, Romans, and British could easily gain striking triumphs. They were not accidentally assembled crusaders [...]. No, they were all warfare nations who fought on German soil, none unworthy of high eighteenth-century culture, some of them equal to the bravest peoples of former times; more than one capable of casting laws upon a continent single-handedly. ${ }^{25}$

According to Archenholz, war reflects the progress of human civilization. He contrasts the Seven Years' War as a between civilized nations, to the wars between civilized nations and barbarian peoples, especially those "from the East." ${ }^{26}$ Though Archenholz uses numerous references to Greek and Roman battles and wars, ${ }^{27}$ he surpasses the ancient model in this idea that the war is perfected in a most civilized world, where its goal is not to civilize other peoples, nor is it to defend the civilized world against barbarian intruders. Fought between civilized nations, war becomes an aesthetic or even sublime undertaking. For example, November 3, 1760 - the day of the Battle at Torgau between Prussians and Austrians - becomes "the most memorable day, when human blood was shed as water, when the total downfall of both most credited and praised armies was at stake, when humans impetuously defied the laws of nature". This general celebration of war in modern civilization is then reinforced by Frederick's "sublime plan" for the battle. ${ }^{28}$ Unlike Tempelhof, Archenholz also reflects upon the hardships and horrors of war. He discusses the impact of Frederick's financial system, the methods of recruiting, the war contributions by cities and provinces, the impact of depreciation, the hardships of the soldiers in the battles and in their winter camps, and the suffering of civilians, most notably in the Prussian siege and bombing of Dresden. ${ }^{29}$

However, this depiction of the suffering of soldiers and civilians is not used to criticize politicians and military commanders; rather, it is

25 GDK, 139.

26 Cf. Fohrmann, "Der Ruhm des Königs," 9.

27 For example GDK, 134, 148f., 350, 389.

28 GDK, 349.

29 GDK, 47-50, 268, 332-338, 366-371, 265-268, 299-307. 
part of a realistic approach to historical narration that surpasses mere strategic and military narratives and moves toward a comprehensive approach to history. The comprehensiveness allows Archenholz to write a history of the progress of civilization instead of merely a history of war.

The second element in this history of cultural progress is the role of the German 'nation' as its vehicle. However, the concept of 'nation,' in which everything in society emerges from and leads into the 'nation,' has not been fully developed in Archenholz. ${ }^{30}$ This German national pride is particularly symbolized by the victory over the French at Roßbach on November 5, 1757, which became a symbol for German national strength in the second half of the eighteenth-century. ${ }^{31}$ The victory at Roßbach against a French army superior in numbers ended the myth of the invincible French and was perceived as a national German event. $^{32}$ Archenholz develops the antagonism between German and French by describing how the common German people started to hate the French because the French treated German culture with contempt. For their part German intellectuals such as Frederick II valued French culture, but they also despised the French attitude toward German culture. Archenholz develops this contempt into a collective national hatred ${ }^{33}$ He tells the story of the Battle at Roßbach in a way that ridicules

30 Fohrmann, "Der Ruhm des Königs," 8f. For more on the role of the Seven Years' War in the development of German Nationalism in eighteenth-century theory and literature, see Hans Peter Herrmann, "Individuum und Staatsmacht: Preußischdeutscher Nationalismus in Texten zum Siebenjährigen Krieg," in P. Herrmann, Hans-Martin Blitz, and Susanna Moßmann, Machtphantasie Deutschland: Nationalismus, Männlichkeit und Fremdenhaß im Vaterlandsdiskurs deutscher Schriftsteller des 18. Jahrhunderts (Frankfurt a.M.: Suhrkamp, 1996), 66-79. There is a longstanding scholarly debate on the concept of the nation and on the emergence of the German nation as well as of German Nationalism. For an example of the latter see Jörg Echternkamp, Der Aufstieg des deutschen Nationalismus (1770-1840) (Frankfurt a.M.: Campus, 1998), for the former Hagen Schulze, States, Nations and Nationalism: From the Middle Ages to the Present, transl. William E. Yuill (Oxford: Blackwell, 1996).

31 Dieter Postier, "Die Schlacht bei Roßbach am 5. November 1757," Militärgeschichte 19 (1980): 685-96; Bernhard R. Kroener, “'Nun danket alle Gott' ... 'bis zur letzten Patrone:' Schlachtenmythen als Bestandteil einer instrumentalisierten kollektiven Erinnerungskultur am Beispiel von Leuthen, Sedan und Stalingrad," Mythen in der Geschichte, ed. Helmut Altrichter, Klaus Herbers and Helmut Neuhaus, Historiae 16 (Freiburg: Rombach, 2004), 397-418, 402. The defeat of the Prussians at Jena and Auerstedt in 1806 strongly diminished the impact of the Battle at Roßbach.

32 Postier, "Die Schlacht," 696. 
French techniques of warfare and demonstrates the French soldiers lack of courage. Though the French forgot their "ridiculous defeat" after a while, the Germans remembered it for a long time: "[...] the word Roßbach still echoed many years later, from the Baltic Sea to the Alps, in disregard of the social status to all French" ${ }^{34}$ Archenholz uses this "national triumph" and its symbolic power to express a German national unity. ${ }^{35}$ The German people achieve a collective voice in their animosity toward the French.

\section{Genius in Warfare and Culture}

In Archenholz' narration of the Battle at Roßbach, military prowess and cultural grandeur are linked. To strengthen this bond, Archenholz exploits the idea of genius. First, his general celebration of war culminates in his celebration of Frederick's tactical genius. This "great genius" becomes the guarantor of the Prussian victory; in the narrative of the Battle at Leuthen, tactical genius is established as the winning counter-force against the quantitative superiority of the Austrians, and is the force by which Prussia must "win" ${ }^{\prime 36}$ and thereby become a major European player. Second, Archenholz transfers the field of warfare to the field of culture. The 1760's and 70's - the era of German Sentimentalism and Sturm und Drang - are regarded as the beginning of the age of genius in German literature. In the writings of Friedrich Gottlob Klopstock, Johann Georg Hamann, Gotthold Ephraim Lessing, among others, the new model of poetic genius and style was developed, a model which surpassed the culture of erudition and the model of French seventeenthcentury classicism. ${ }^{37}$ Ancient traditions and norms and strict rhetorical and poetic rules were de-emphasized, and the role of the subject mat-

35 GDK, 115.

$36 G D K, 131$. Prussia did not formally win the war, but survived and kept Silesia. In Archenholz' representation, the 'draw' between the war parties becomes a symbolic victory.

37 For an historical overview of this aspect of German aesthetics, see Jochen Schmidt, Die Geschichte des Genie-Gedankens in der deutschen Literatur, Philosophie und Politik 1750-1945, vol. 1, Von der Aufklärung bis zum Idealismus, 3rd ed. (Heidelberg: Winter, 2004); for the French background of the word and concept of 'génie,' see Hubert Sommer, génie: Zur Bedeutungsgeschichte des Wortes von der Renaissance zur Aufklärung, ed. Michael Nerlich, Artefakt 6 (Frankfurt am Main: Lang, 1998). 
ter and the poet were elevated. Genius is seen to create from within itself, its aesthetic subjectivity innate. The source of art, the 'original genius' ('Originalgenie'), does not rely on exterior nature. ${ }^{38}$ However, in the 1760's the genius is still closely related to rhetorical principles and poetic rules, ${ }^{39}$ and this relationship is the basis of Archenholz' comparisons of eighteenth-century warfare with that of ancient Greece and Rome. Historians at this time employ the idea of historia magistra vitae, of exemplary history. This shows that Archenholz is still part of the old rhetorical tradition, at the same time, he deviates from this rhetorical tradition by developing the idea of genius in warfare and culture. $\mathrm{He}$ celebrates the new German cultural genius emphatically: "There had never been a people who had such a quick and admirable revolution of thought; such human greatness had never been seen in more manifold forms, than now" ${ }^{40}$ The literary genius is projected onto all German culture, onto the other arts and sciences. ${ }^{41}$ For example, Archenholz notes how physicians have begun to talk and write comprehensibly instead of merely following the Greek model. ${ }^{42} \mathrm{~A}$ German revolution of thought "sweeps" over the German states and Europe, and becomes the vehicle of humankind's progress of civilization. ${ }^{43}$

The transition from erudition to genius is exactly what Archenholz' historical writing achieves for German historiography around 1790. The historiographical text itself becomes the decisive vehicle of history. It is now possible to narrate history with an overall narrative structure instead of recounting many facts that cannot be united, and for Archenholz, it becomes possible to re-stage this historical process. History becomes temporalized; the open-ended process of history comes to the foreground. Past and future are inter-related, but a past event can never be repeated as such, so each event is singular in time. ${ }^{44}$

38 Christian Begemann, "Der Körper des Autors: Autorschaft als Zeugung und Geburt im diskursiven Feld der Genieästhetik," in Autorschaft: Positionen und Revisionen, ed. Heinrich Detering, Germanistische Symposien Berichtsbände 24 (Stuttgart: Metzler, 2002), 44-61, 46.

39 For Lessing's concept of genius, see Schmidt, Die Geschichte des Genie-Gedankens, 74-95.

40 GDK, 400.

41 GDK, 400-3.

42 GDK, 401.

43 GDK, 401.

44 Koselleck, “Historia Magistra Vitae," 58-61. 
This performance of history's process - 'little Prussia' defies several big empires - refers to the events of the war on the first level. On the second level, the performance of history exceeds the specific narrative of the Seven Years' War to encompass a narrative of cultural progress. The Prussian values and achievements are transferred to a German identity, and this Germanness guarantees human progress, which has reached a new and higher stage of human development through this war between the most highly civilized peoples. War enables civilization. For Archenholz, the Seven Years' War is just the beginning of the "national happiness" that starts a "great cultural epoch".

\section{German Historiography's New Modernity}

In conclusion, Archenholz' History of the Seven Years' War displays and performs the process of history by staging a battle of forces. This battle takes place on two levels: as a speech act, in the speech by which Frederick convinced his generals of their strength, and as tactical moves in a real battle - for example the flanking maneuver which won the Battle at Leuthen. Archenholz rhetorically influences the reader, and provokes the same reaction as seen in Frederick's soldiers or his opponents. They are impressed and respond to his apparent genius. The reader is drawn into the teleological development Archenholz establishes. Just as Frederick's listeners at Leuthen had to believe their commander, the reader has no choice except to admire this impossible Prussian 'victory' that defies all reason. Despite the many contingencies in Archenholz' text, Prussian warfare and German culture bring civilization to its next level. Instead of merely arguing the merits of this greatness, Archenholz also proves it by a textual performance. Though sometimes the text sounds like a hymn to Prussian and German national grandeur, and though he predominantly uses Prussian sources, Archenholz sticks to the most reliable sources to which he would have had access at that time; he is critical, even of Frederick II. ${ }^{46}$ Archenholz' technique of staging history as a process allows him to be taken seriously as a scholar of the late eighteenth-century; all the contingencies, such as flaws in Frederick's character or outright mistakes by the Prussians, can be fully integrated to the overall framework of the narrative in a process which guarantees meaning in history itself. 
With Archenholz' History of the Seven Years' War, German historiography receives one of its first modern narratives. On the borderline between rhetoric and modern historical analysis, German identity is created out of war. Historical events may be contingent; nonetheless, Archenholz made history narratable and created a forceful historical meaning that pushed the German nation, long before it was politically realized in 1871, to the forefront of the process of civilization.

STEPHAN JAEGER

University of Manitoba 